УДК $811.11(072)$

Ю. О. Березіна

\title{
СИСТЕМА НІМЕЦЬКИХ ПРИГОЛОСНИХ І ОСОБЛИВОСТІ ЇХ АРТИКУЛЯЦІї
}

Березіна Ю. О. Система німецьких приголосних і особливості їх артикуляції.

У статті йдеться про систему приголосних у німецькій мові, що розподіляються за способом вимови на чотири групи та становлять артикуляційну базу німецької мови. У роботі розглядаються особливості вимови відповідних приголосних.

Ключові слова: фонетика, німецька мова, система приголосних, артикуляція, фонеми.

Березина Ю. О. Система немецких согласных и особенности их артикуляции.

В статье идет речь о системе согласных в немецком языке, которые разделяются за способом произношения на четыре группы и являют собой артикуляционную базу немецкого языка. В работе рассматриваются особенности произношения данных согласных.

Ключевые слова: фонетика, немецкий язык, система согласных, артикуляция, фонемы.

Berezina J. O. The System of German consonants and specifics of their articulation.

The article deals with the consonant system in German, which are divided by method of articulation in four groups and are the articulate base in German language. In the research the articulation of the consonants is considered as well.

Key words: phonetics, German, consonant system, articulation, phonemes.

Постановка проблеми. На сьогодні існує багато досліджень, фонологічних та фонетичних, як артикуляторних, так і акустичних, які пов'язані 3 системою консонантизму в сучасній німецькій мові i визначають систему консонантизму загалом. На жаль, більшість науковців розглядає проблему вимови німецьких звуків у синхронії, що не дає змоги поступово простежити процеси розвитку та зробити фундаментально обгрунтовані висновки. Запропонована стаття $\epsilon$ частиною діахронічного дослідження, що дозволить не тільки зробити висновки більш об'єктивними, але й визначити тенденцію майбутнього розвитку німецьких приголосних.

Актуальність дослідження. Будь-яка мова є відображенням життя суспільства у визначений період часу. Історичні події мають неабиякий вплив на всі рівні мови. Відомо, що сучасне германське мовознавство динамічно розвивається, 3 часом відзначаються зміни вимови звуків та фіксуються особливості їх артикуляції, виявляються

(С) Ю. О. Березіна, 2014. 
значні суперечності між вимовою й орфографією, які можна пояснити 3 позиції фонетичного і лексичного принципів. Сучасна фонетика характеризується посиленням інтересу до проблем, пов'язаних із природою фонетичних явищ саме в діахронічному аспекті. У нашій статті представлено аналіз досліджень німецьких приголосних зарубіжних і вітчизняних науковців та на основі вивченої літератури опис особливостей артикуляціі приголосних.

Постановка завдання. На основі викладеного можна сформулювати завдання дослідження, яке полягає у вивченні наукової літератури з відповідної теми, аналізі досліджень відомих фонетистів та сучасних науковців для встановлення особливостей артикуляції консонантної системи в німецькій мові.

Метою наукової статті є визначення характерних рис сучасної німецької системи приголосних.

Аналіз досліджень і публікацій. За даними різних дослідників $[3$, с. 39-50], [4, с. 59], [5, с. 104-108], [7, с. 150-157], [9, с. 19-20] та ін.) відзначається чимало підходів до характеристики приголосних. Зупинимося на основних особливостях складу приголосних німецької мови.

Німецька система приголосних нараховує, згідно 3 думкою більшості дослідників, 24 фонеми, усі вони протиставляються одна одній в однаково вимовлених умовах, наприклад: Reiben [b] - терти, Reifen [f] - зріти; (der) Reigen[g] - хоровод, Reimen [m] - pимувати; Reisen [z] - подорожувати, Reiten [t] - їхати верхи, Reizen [ts] дражнити, дратувати і т. ін.

У німецькій, як і в інших мовах, розрізняють голосні та приголосні. Оскільки розрізнення голосних і приголосних, незважаючи на те, що воно в різних мовах функціонує по-різному, є універсальним, властивим усім мовам, воно повинно бути зумовлене акустико-фізіологічною природою плану вираження мови. Загальна фонетика здавна прагне знайти для цього розрізнення акустичні або фізіологічні підстави.

Коли характеризують відмінність між голосними й приголосними у фізіологічному плані, то найчастіше говорять про наявність чи відсутність перепони для виходу з легень струменя повітря. Перша ознака властива утворенню приголосних, друга - голосних. Трапляється у фонетичній літературі й дещо інше формулювання того ж фізіологічного критерію розрізнення голосних і приголосних. Таке формулювання ми знаходимо в одного 3 найвизначніших 
фонетистів В.А. Богородицького, на думку якого голосні утворюються завдяки розкриваючим рухам вимовляючих органів (у першу чергу нижньої щелепи), а приголосні - завдяки закриваючим. Для підтвердження своєї позиції В.А. Богородицький покликався на такий експеримент: «для 3'ясування розходжень між голосними i приголосними щодо звукоартикуляції треба вказати на важливість досліджень над посиленням вимови тих чи тих звуків» [1, с. 15]. Якщо провести аналогічне дослідження з голосними, то виявиться, що для посилення останнього зовсім не потрібно розкривати нижню щелепу. Отже, узагальнений висновок, який робить В. А. Богородицький, неправильний. Так, у наведених думках є доля істини, при утворенні шуму приголосного необхідно створити перешкоду для струменя повітря, задля чого доводиться робити закриваючий рух вимовляючих органів. Але наявність перешкоди, те чи те положення органів саме по собі ще не робить характеристику звука. Можна дуже високо підняти язик, створюючи таким чином дуже вузьку щілину, а водночас вимовити не приголосний, а голосний. Суттєве значення для розрізнення голосних та приголосних має і ступінь легкості, тобто сила видихованого повітря.

Німецькі приголосні протиставляються один одному за глухістю та дзвінкістю. Наприклад: Teer - der, fegen - wegen, Poren - bohren, Weiße - Weise, Laken - Lagen, können - gönnen.

Зімкнено-вибухові приголосні. При артикуляція німецьких приголосних [p] і [b] губи щільно стиснуті, м'яке піднебіння підняте, видихуване повітря накопичується в порожнині рота перед змичкою. Миттєвий рух губ розмикає змичку, повітря спрямовується в отвір, що утворився 3 характерним шумом, подібним до вибуху. При [р] голосові зв'язки пасивні, при [b] вони вібрують. Німецьким приголосним [p] i [b] характерні слабке напруження м'язів. Крім того, німецьке [р] вимовляється на дуже сильному видиху, завдяки чому в ротовій порожнині перед змичкою утворюється багато повітря. Ця повітряна маса виробляє при розмиканні змички додатковий глухий шум, так званий придих. Таким чином, [p] - це глухий, a [b] дзвінкий двогубний зімкнено-вибуховий приголосний. Причому [p] може траплятися в будь-якій позиції, [b] не трапляається в кінці слова і перед глухими приголосними, наприклад: der Pilz [pIlts], halb [halp].

При вимові німецького глухого [t] i дзвінкого [d] кінчик язика притискається до альвеол передніх верхніх зубів, утворюючи щілинну 
змичку, німецькі [t] i [d] - це альвеолярні приголосні. Що стосується вимови, то [t] так само, як і [p], вимовляється на сильному видиху. Повітря наповнює порожнину рота перед перешкодою так, що вибух супроводжується шумом придиху. При цьому [t] відзначається як глухий, a [d] як дзвінкий зімкнено-вибуховий передньоязиковоальвеолярний приголосний. Відомо, що [t] може вимовляється в будьякій позиції, а [d] відсутній на кінці слова і перед глухими приголосними, наприклад: fort [fjet], bald [balt].

Німецькі [k] i [g] вимовляються так: задня частина спинки язика піднімається до м'якого піднебіння й утворює з ним змичку; передня і середня частина язика лежать плоско. М'яке піднебіння підняте. При вимові німецького [k] видих значно сильний, тому звук вибуху [k] також супроводжується придихом. Отже [k] - це глухий, a [g] дзвінкий задньоязиковий, зімкнено-вибуховий приголосний. Вимова [k] не обмежена позицією, [g] відсутній на кінці слова і перед глухими приголосними.

Зімкнено-щілинні приголосні. При артикуляції німецької фонеми [pf] губи спочатку утворюють змичку, як для [p], але при цьому край нижньої губи загнутий усередину і притиснутий до краю передніх верхніх зубів. Вибух змички відбувається не швидко й енергійно, як при [p], а змичка миттєво переходить у щілину, як для [f], утворюється злитий приголосний [pf]. М'язи губ сильно напружені. Отже [pf] - це глухий губно-зубний зімкнено-щілинний приголосний, наприклад: $\operatorname{der}$ Pfad [pfa: t], der Napf [napf].

При артикуляції фонеми [ts] спочатку кінчик та передня частина спинки язика притискаються до альвеол, але ця змичка негайно ж переходить у щілину, так що утворюється злитий звук, м'язи напружені. При утворенні німецького [ts] беруть участь одночасно і кінчик, і передня спинка язика. Відповідно, [ts] - це передньоязиковий зімкнено-щілинний приголосний. Відомо, що фонема [ts] трапляється в будь-якій позиції, наприклад: der Zopf [tsopf],der Satz [zats].

При вимові німецького [tsch] кінчик та передня частина спинки язика притиснуті високо до альвеол на початку твердого піднебіння. Отримана таким шляхом змичка зразу ж переходить в щілину, яка утворюється одночасно зі змичкою підняттям передньої спинки язика до м'якого піднебіння. Середня частина спинки язика спущена, м'язи сильно напружені і звук виходить злитий. Німецьке [tsch] вважається завжди твердим, глухим альвеолярним, зімкнено-щілинним 
приголосним, який займає будь-яке місце у слові.

Зімкнено-прохідні приголосні. Німецьке [m] артикулюється таким чином, що нижня і верхня губи утворюють змичку, як для [b], але м'яке піднебіння опущене, змичка не вибухає і видих йде через порожнину носа. Німецькому [m] характерна значна напруженість i тривалість, які помітні особливо після коротких голосних. Цей $[\mathbf{m}]-\epsilon$ двогубним носовим зімкнено-прохідним приголосним, позиційно не пов'язаним, наприклад: mit [mit], komm [kom].

При вимові німецького [n] кінчик язика піднятий і притиснутий до альвеол, край передньої частини язика торкається верхніх зубів, середня частина його лежить у площині. М'яке піднебіння опущене i повітря виходить через носову порожнину. Отже, [n] - це передньоязиково-альвеолярний зімкнено-прохідний приголосний, що вимовляється в будь-якій позиції, наприклад: wann [van], wen [ve: n].

При вимові німецького [l] кінчик язика притиснутий до альвеол, вся інша частина язика лежить плоско, опущені також бокові краї язика, так що вони ніде не стикаються з верхніми боковими зубами. Змичка утворюється тільки між кінчиком язика й альвеолами. М'яке піднебіння підняте, і видиховане повітря проходить через ротову порожнину по обидва боки язика, тобто між його боковими краями $і$ верхніми боковими зубами. Німецьке [1], як і всі німецькі приголосні, артикулюється 3 сильним м'язовим напруженням. Він $є$ боковим передньоязиково-альвеолярним зімкнено-прохідним і вимовляється в будь-якій позиції, наприклад: die Lust [lost], die Welt [velt].

Щілинні приголосні. При вимові щілинних приголосних [f], [v], [s], [z], [j] змичка поступово переходить у щілину. Графічно вищезазначені звуки позначаються буквами $\mathbf{f}, \mathbf{v}, \mathbf{w}, \mathbf{s}, \mathbf{j}, \mathbf{i}$.

При вимові [r] кінчик язика піднятий до альвеол, м'язи язика напружені, бокові краї язика доторкаються до верхніх зубів, м'яке піднебіння підняте. Між кінчиком язика й альвеолами утворюється дуже вузька щілина. Видиховане повітря, проштовхуючись у цю щілину, призводить кінчик язика в коливальні рухи, завдяки чому щілина стає поперемінно ширшою. Цей [r] прийнято вважати передньоязиково-альвеолярним щілинним приголосним.

Крім передньоязикового, існує інший приголосний тремтячеязичковий $[\mathbf{R}]$. Цей приголосний відкидався нормою вимови, тому що його погано чути зі сцени; тепер [R] визнається рівноправним факультативним варіантом фонеми [r]. При [R] щілина виникає між 
опущеним маленьким язичком і піднятою задньою спинкою язика, а звук утворюється коливальними рухами язичка. Обидва варіанти - [r] i [R] - вимовляються в будь-якій позиції. Наприклад: wer [ve:s], der Rhein 「raEkn].

Глухий щілинний приголосний [h], здебільшого трапляється тільки на початку слова або морфем, перед голосним. Графічно він також відображений буквою $\mathbf{h}$, наприклад: der Held, harren, behandeln, vorher. Оскільки буква $\mathbf{h}$ служить і для позначення тривалості голосного, а вживання його подекуди пояснюється тільки традицією, то необхідно уникати вимови [h] у такому разі, як ruhig.

Висновки. У результаті вивчення вітчизняної та іноземної літератури стосовно приголосних фонем німецької мови на артикуляційному рівні, ми прийшли до висновку, що в німецькій мові наявні чотири групи приголосних звуків, які розрізняються за способом вимови та становлять артикуляційну базу німецьких приголосних. Це зімкнено-вибухові, зімкнено-щілинні, зімкненопрохідні та щілинні приголосні. Усе це має велике значення не тільки при вивченні іноземної мови, але й у методиці їі викладання.

\section{Література}

1. Богородицкий В. А. Введение в изучение современных романских и германских языков / В. А. Богородицкий. - М. : Изд-во лит-ры на иностр. яз., 1969. - 184 с.

2. Потапова Р. К. Особенности немецкого произношения / Р. К. Потапова, Г. Линднер. - М. , 1991. -319 с.

3. Прокопова Л. І. Вступний курс фонетики німецької мови для вузів / Л. І. Прокопова. - К. : КиМУ, 2003. - 136 с.

4. Скалозуб Л. Г. Динамика звукообразования (по данным кинорентгенографирования)/ Л. Г. Скалозуб. - К. : Высшая школа. Главное из-во, 1979. - 132 с.

5. Таранец В. Г. Энергетическая теория речи : [монография] / В. Г. Таранец. Одесса : Печатный дом, 2014. - [2-ое изд., доп.]. - 146 с.

6. Augustin Speyer. Deutsche Sprachgeschichte / Augustin Speyer. - Göttingen : Vandenhoeck \& Ruprecht, 2010. - 128 S.

7. Sievers E. Grundzüge der Phonetik / E. Sievers. - Leipzig. - Band I, 4. verb. Aufl., 1893. $-298 \mathrm{~s}$.

8. Staffeldt Sven. Einführung in die Phonetik, Phonologie und Grammatik des Deutschen / Sven Staffeldt. - Tübingen : Stauffenburg Verlag, 2010. - 191 s.

9. Verbitskaja T. D. Deutsch akzentfrei. Kommunikativ-orientierter phonetischer Einführungskurs, 2. neu bearbeitete und erweiterte Auflage / T. D. Verbitskaja, T. V. Grischina. - Odessa : Astroprint, 2014. - 136 s.

Стаття надійшла до редакиії 27.08.2014 p. 